\title{
STEAM DAN PEMBELAJARAN BERBASIS PROYEK UNTUK MENGEMBANGKAN KREATIVITAS SISWA
}

\author{
STEAM and Project Based Learning to Develop Student's Creativity
}

\author{
Andriani \\ SMPN 3 Sumbawa Besar, Sumbawa, Nusa Tenggara Barat \\ *)E-mail korespondensi: andriani.1973@gmail.com
}

\begin{abstract}
This study aims to analyze how Project-Based Learning with the STEAM approach can (1) develop student's creativity, and (2) foster environmental awareness through the use of used plastic. This research is a pre-experimental type of oneshot case study with the participants of class IX. The data collection instruments were observation sheets and project report assessment sheets which were used to assess students' creativity in the cognitive realm using indicators of creative thinking abilities. Product appraisal sheet was used for assessing the psychomotor domain with creative product indicators and STEAM integration in products. Meanwhile, the realm of attitudes used observation sheets to observe student behavior related to caring attitudes towards the school environment. Furthermore, data analysis was carried out by changing the scores obtained into the form of values associated with the student's creativity categories. The results of the data analysis showed that the student's creativity in the cognitive domain was in good category with the score of 73\%, the psychomotor domain was in very good category with the score of $90 \%$, and the attitude domain was in good and very good predicate. The activities carried out by students with this learning model encourage students to think creatively and produce creative products.
\end{abstract}

Keywords: Project Based Learning, STEAM approach, student creativity.

\begin{abstract}
ABSTRAK
Penelitian ini bertujuan untuk menganalisis bagaimana Pembelajaran Berbasis Proyek dengan pendekatan STEAM dapat (1) mengembangkan kreativitas siswa, dan (2) menumbuhkan kepedulian lingkungan melalui pemanfaatan plastik bekas. Penelitian ini adalah pre-experimental jenis one-shot case study dengan partisipan 30 siswa kelas IX. Instrumen pengumpulan data berupa lembar observasi dan lembar penilaian laporan proyek yang digunakan untuk menilai kreativitas siswa pada ranah kognitif menggunakan indikator kemampuan berpikir kreatif. Lembar penilaian produk untuk menilai ranah psikomotorik dengan indikator produk kreatif dan integrasi STEAM dalam produk. Sedangkan ranah sikap menggunakan lembar observasi untuk mengamati perilaku siswa terkait sikap peduli terhadap lingkungan sekolah. Selanjutnya dilakukan analisis data dengan mengubah skor yang diperoleh kedalam bentuk nilai yang dikaitkan dengan kategori kreativitas siswa. Hasil analisis data menunjukkan bahwa kreativitas siswa pada ranah kognitif berkategori baik dengan skor 73\%, ranah psikomotorik berkategori sangat baik dengan skor 90\%, dan ranah sikap dengan predikat baik dan sangat baik. Aktivitas-aktivitas yang dilakukan siswa dengan model pembelajaran ini mendorong siswa untuk berpikir kreatif dan menghasilkan produk yang kreatif.
\end{abstract}

Kata kunci: Pembelajaran Berbasis Proyek, Pendekatan STEAM, Kreativitas siswa.

\section{PENDAHULUAN}

Pembelajaran abad 21 menuntut guru untuk membekali siswa dengan keterampilan dan kemampuan berpikir yang dapat menjadikan mereka sebagai individu-individu cerdas, mandiri, unggul, dan tangguh yang mampu bertahan di abad 21. Keterampilan abad 21 ini meliputi berpikir kreatif dan inovasi (creativity thinking and innovation), berpikir kritis dan pemecahan masalah (critical thinking and problem solving), komunikasi (communication) dan kerjasama (collaboration) atau dikenal dengan 4Cs (Ditjen GTK Kemendikbud, 2018).

Semua keterampilan ini dapat diperoleh peserta didik jika pendidik mampu mengembangkan pembelajaran dengan kegiatan yang menantang peserta didik untuk berpikir kritis dalam memecahkan masalah, kegiatan yang mendorong kerja sama dan komunikasi, serta menumbuhkan ide-ide kreatif dan inovatif. Salah satu model pembelajaran yang dapat digunakan adalah Pembelajaran Berbasis Proyek. Warsono dan Hariyanto (2012: 153) menyatakan Pembelajaran Berbasis Proyek sebagai suatu pengajaran yang mengaitkan teknologi dengan masalah kehidupan sehari-hari atau dengan suatu proyek di sekolah. Dalam Pembelajaran Berbasis Proyek, siswa dituntut untuk berpikir kritis menyelesaikan masalah dengan cara menganalisis, berargumen, 
mengevaluasi, menentukan langkah apa yang harus diambil, menyimpulkan dan memunculkan wawasan terhadap tiap-tiap permasalahan melalui kerja sama dan komunikasi antar peserta didik (Dirjen Dikdasmen, 2016). Penerapan model Pembelajaran Berbasis Proyek menuntut siswa menyelesaikan suatu proyek dalam kehidupan sehari-hari.

Proses berpikir siswa dalam menyelesaikan proyek membutuhkan suatu pendekatan pembelajaran. Pendekatan pembelajaran yang dapat diintegrasikan dengan Pembelajaran Berbasis Proyek adalah pendekatan STEAM (Science, Technology, Engineering, Arts and Mathematic). Menurut Henrisken (2014) dengan STEAM peserta didik dapat memperkuat pembelajaran mereka pada seluruh disiplin ilmu dan mendapat kesempatan untuk mengeksplorasi dan membuat hubungan seni, sains, dan lainlain. Pembelajaran dengan pendekatan STEAM merupakan pembelajaran konstektual yang mengajarkan ilmu sains, teknologi, teknik, dan matematika secara terpadu dengan menambahkan unsur seni dalam kegiatan pembelajarannya, dimana peserta didik akan diajak memahami fenomenafenomena yang terjadi di kehidupan sehari-hari (Yakman, 2012).

Pembelajaran Berbasis Proyek dengan pendekatan STEAM (PBP-STEAM) merupakan suatu pembelajaran yang mengintegrasikan setiap komponen STEAM dalam Pembelajaran Berbasis Proyek. Penerapan pembelajaran ini dilakukan dengan memberikan aktivitas pembelajaran berupa proyek dengan mengintegrasikan komponen-komponen STEAM, yaitu Science menjelaskan tentang pemahaman konsep materi pengetahuan, Technology menjelaskan penggunaan teknologi yang memudahkan siswa dalam melakukan aktivitas, Engineering berkaitan dengan cara mendesain yang dilakukan siswa dalam menyelesaikan proyek, Arts sebagai produk hasil kreativitas siswa, dan Mathematics yang berhubungan dengan kuantitas, angka, bentuk, dan ruang yang digunakan siswa dalam aktivitas pembelajaran (Hadinugrahaningsih, et al; 2017).

Salah satu keterampilan abad 21 yang perlu dibekali pada siswa adalah kreativitas. Kreativitas merupakan kemampuan seseorang untuk menghasilkan gagasan atau karya nyata yang baru. Menurut Munandar (2012: 45), kreativitas dipengaruhi oleh empat aspek, yaitu pribadi, pendorong, proses dan produk. Ini berarti kreativitas terdiri dari berbagai ranah yaitu ranah kognitif (berpikir kreatif), ranah afektif (sikap dan kepribadian) dan ranah psikomotor (keterampilan kreatif). Kreativitas dalam penelitian ini menilai ranah kognitif dan psikomotorik. Penilaian ranah kognitif memberikan gambaran tentang kemampuan berpikir kreatif siswa. Sedangkan penilaian keterampilan dilakukan melalui produk kreatif yang dihasilkan siswa lewat penugasan proyek.

Untuk mengembangkan kreativitas siswa melalui PBP-STEAM dalam penelitian ini berupa penugasan proyek dengan tema menghias pojok ruangan dengan rak dan bunga, memanfaatkan limbah plastik bekas, kertas dan sisa-sisa kayu dari meja-meja yang rusak. Ide penggunaan plastik bekas dalam proyek ini didasarkan atas kondisi lingkungan di sekolah. Setiap hari, sekolah menghasilkan banyak sampah plastik yang berasal dari bekas botol minuman ataupun bungkus makanan. Penggunaan barang bekas sebagai media pembelajaran bertujuan mengajarkan siswa untuk menjaga dan melestarikan lingkungan sehingga tercipta lingkungan yang asri, bersih, dan sehat dengan memanfaatkan limbah atau sampah plastik menjadi barang yang lebih berharga.

Tujuan penelitian ini untuk menganalisis bagaimana pembelajaran berbasis proyek dengan pendekatan STEAM dapat (1) mengembangkan kreativitas siswa, dan (2) menumbuhkan kepedulian lingkungan melalui pemanfaatan plastik bekas.

\section{METODE}

Penelitian ini merupakan pre-experiment dengan jenis one-shot case study yang dilakukan pada siswa kelas IX.B di SMPN 3 Sumbawa Besar pada semester genap tahun pelajaran 2018/2019 yang berjumlah 30 orang, terdiri dari 14 siswa perempuan dan 16 siswa laki-laki. Tema yang dipilih terkait dengan materi Bangun Ruang Sisi Lengkung (BRSL) dengan Kompetensi dasar yaitu menyelesaikan masalah kontekstual yang berkaitan dengan luas permukaan dan volume bangun ruang sisi lengkung (tabung, kerucut, dan bola), serta gabungan beberapa bangun ruang sisi lengkung.

Pada kelas eksperimen ini dilakukan pembelajaran dengan menggunakan PBP-STEAM dengan langkah-langkah pembelajaran mengacu pada tahapan Pembelajaran Berbasis Proyek yang terdiri dari enam tahapan (Dirjen Dikdasmen, 2016), yaitu: 
a) Penentuan proyek

Pada pembelajaran ini, proyek yang dilakukan siswa berupa pembuatan pot bunga dari botol plastik yang dihiasi dengan cara melilitkan tali dari plastik berwarna pada botol, penanaman bunga pada pot, dan pembuatan rak bunga.

b) Perancangan langkah-langkah penyelesaian proyek

Siswa melakukan perencanaan proyek dengan mencari informasi tentang cara penyelesaian proyek berupa langkah-langkah kegiatan penyelesaian proyek, perumusan tujuan dan hasil akhir yang diinginkan, perencanaan bahan dan alat yang digunakan, serta teknik yang dipakai untuk menghasilkan produk akhir.

c) Penyusunan jadwal pelaksanaan proyek

Siswa bersama guru melakukan penjadwalan semua kegiatan yang telah dirancang terkait berapa lama proyek itu diselesaikan tahap demi tahap. Pada pertemuan pertama proyek yang dilakukan adalah pembuatan pot bunga. Pertemuan kedua melakukan pembuatan rak bunga, dan pertemuan ketiga berupa penanaman bunga di pot serta pengaturan tempat hasil produk.

d) Penyelesaian proyek dengan fasilitas dan monitoring guru

Selama siswa bekerja menyelesaikan proyek, guru membimbing dan memonitoring aktivitas siswa dalam melakukan tugas proyek. Siswa mencari dan mengumpulkan data dan kemudian menyusun bagian demi bagian sampai dihasilkan produk akhir.

e) Penyusunan laporan dan presentasi hasil proyek

Pada tahap ini, siswa melakukan presentasi hasil proyek dan menyusun laporan proyek

f) Evaluasi proses dan hasil proyek

Guru dan siswa melakukan evaluasi terhadap kegiatan pembelajaran dan hasil proyek yang telah dilaksanakan. Evaluasi mengenai kendala-kendala dan solusi yang dilakukan siswa selama penyelesaian proyek serta perasaan siswa terkait pembelajaran.

Pada pelaksanaan PBP-STEAM, guru melakukan pengumpulan data selama proses kegiatan berlangsung. Instrumen yang digunakan berupa lembar penilaian laporan proyek, lembar penilaian produk, dan lembar observasi kemampuan berpikir kreatif.

Lembar observasi digunakan untuk menilai kemampuan berpikir kreatif siswa yang meliputi aspek kelancaran (fluency), keluwesan (flexibility), keaslian (originality) dan keterperincian (elaboration) dengan indikator seperti terlihat pada Tabel 1 berikut. Setiap indikator diberi skor dengan ketentuan skor 4 untuk kriteria sangat baik, 3 untuk kriteria baik, 2 untuk kriteria cukup baik, dan kurang baik dengan skor 1.

Tabel 1. Hasil penilaian keterampilan proses

\begin{tabular}{|c|c|c|}
\hline No & Aspek berpikir kreatif & Indikator \\
\hline 1 & kelancaran & $\begin{array}{l}\text { Lancar dalam memberikan jawaban ataupun mengemukakan } \\
\text { pendapat atau ide-ide }\end{array}$ \\
\hline 2 & keluwesan & $\begin{array}{l}\text { Memberikan berbagai alternatif dalam menyelesaikan } \\
\text { permasalahan }\end{array}$ \\
\hline 3 & keaslian & Memberikan ide atau karya hasil pemikirin sendiri \\
\hline 4 & keterperincian & Dapat mengembangkan atau merinci gagasan/ide \\
\hline
\end{tabular}

Lembar penilaian laporan proyek untuk menilai laporan proyek siswa dengan pedoman penilaian seperti terlihat pada Tabel 2 . Rubrik penilaian berisi rentang skor $1-3$ untuk setiap indikator. 
Tabel 2. Lembar penilaian laporan proyek

\begin{tabular}{llll}
\hline No & \multicolumn{1}{c}{$\begin{array}{c}\text { Komponen } \\
\text { Penilaian }\end{array}$} & $\begin{array}{c}\text { Aspek berpikir } \\
\text { kreatif }\end{array}$ & \multicolumn{1}{c}{ Indikator } \\
\hline 1 & Judul & Keaslian & Menuliskan judul yang berbeda dengan yang lain \\
2 & Tujuan & Kelancaran & Mengemukakan tujuan secara jelas dan lancer \\
3 & Dasar teori & Keaslian & Menyertakan dasar teori yang sesuai dan berbeda dengan yang lain \\
4 & Alat dan bahan & Keterperincian & Menuliskan alat dan bahan yang dipakai secara rinci \\
5 & Prosedur kerja & Keterperincian & Menuliskan prosedur kerja secara rinci \\
& & Kelancaran & Mengemukakan prosedur kerja secara lancar \\
6 & Hasil dan & Keterperincian & Menuliskan hasil dan pembahasan secara rinci \\
& pembahasan & Keluwesan & Mengemukakan banyak gagasan dalam pembahsan \\
7 & Kesimpulan & Keluwesan & Membuat kesimpulan yang sesuai dengan tujuan \\
8 & Daftar pustaka & Keluwesan & Menyertakan daftar pustaka yang sesuai \\
\hline
\end{tabular}

Lembar penilaian produk untuk menilai hasil produk siswa berdasrkan kriteria produk kreatif dan integrasi unsur-unsur STEAM dengan skor 4 untuk kriteria sangat baik, 3 untuk kriteria baik, 2 untuk kriteria cukup baik, dan kurang baik dengan skor 1, untuk masing-masing unsur STEAM. Kriteria produk kreatif meliputi keaslian (originality), pemecahan (resolution), dan keterperincian (elaboration).

Data yang diperoleh dianalis untuk mengetahui kategori kreativitas siswa. Tahap pengolahan data meliputi: (a) verifikasi data, yaitu mengecek kembali kelengkapan jumlah dan pengisian lembar observasi dan penilaian, (b) tabulasi data, merekap data yang telah diperoleh, (c) Penyekoran data, melakukan penilaian dengan menggunakan kategori skor yang telah ditetapkan sebelumnya. Setelah skor didapat, maka dilakukan penghitungan untuk mengetahui nilai siswa dengan menggunakan rumus:

Nilai $=\frac{\text { jumlah skor yang diperoleh }}{\text { skor maksimal }} \times 100 \%$

(d) Menarik kesimpulan dengan menentukan kategori kreativitas siswa dengan ketentuan seperti pada tabel berikut.

Tabel 3. Kategori kreativitas siswa

\begin{tabular}{ll}
\hline Nilai & Kategori \\
\hline $86 \%-100 \%$ & Sangat Baik \\
$71 \%-85 \%$ & Baik \\
$56 \%-70 \%$ & Cukup \\
$41 \%-55 \%$ & Kurang \\
$\leq 40 \%$ & Tidak Baik \\
\hline
\end{tabular}

Lembar observasi sikap digunakan untuk melihat perilaku siswa terkait kepedulian terhadap lingkungan dengan indikator: (1) membuang sampah pada tempatnya, (2) memisahkan sampah plastik dengan sampah jenis lainnya, (3) memelihara lingkungan sekolah, dan (4) tidak merusak tanaman di lingkungan sekolah. Lembar observasi terdiri dari 10 butir pernyataan yang diisi dengan mencentang penilaian pada kolom "ya" atau "Tidak" pada setiap lembar penilaian siswa. Pengamatan dilakukan selama pelaksanaan proyek. 


\section{HASIL DAN PEMBAHASAN}

Pembelajaran menggunakan model PBP-STEAM dilaksanakan pada materi Bangun Ruang Sisi Lengkung (BRSL). Sebelum melakukan pembelajaran, guru membuat RPP, lembar penilaian laporan proyek, lembar penilaian produk, dan lembar observasi kemampuan berpikir kreatif. Pembelajaran PBP-STEAM akan menghasilkan suatu produk. Guru membagi siswa menjadi 5 kelompok heterogen berdasarkan kemampuan akademik dan jenis kelamin.

Integrasi STEAM pada pelaksanaan Pembelajaran Berbasis Proyek dapat diuraikan sebagai berikut.

1) Science

Unsur Science berupa aktivitas siswa menanam bunga dalam pot dengan memperhatikan jenis tanaman dan perkembangbiakannya. Siswa diminta untuk mencari informasi tentang bunga yang ditanam, baik nama maupun cara perkembangbiakannya.

\section{2) Technology}

Siswa menggunakan internet dalam mencari informasi terkait proyek yang akan dilakukan. Informasi itu berupa model rak bunga, alat dan bahan yang digunakan serta informasi lain yang menunjang penyelesaian proyek.

\section{3) Engineering}

Pemilihan gambar/model rak bunga dengan mempertimbangkan efisiensi dan bentuk ruang kelas. Gambar rak bunga yang telah mereka siapkan, kemudian dikonstruksi ulang sesuai dengan penempatannya.

\section{4) Arts}

Produk yang dihasilkan merupakan karya seni yang dapat digunakan untuk menghias ruang dan teras kelas. Pemanfaatan barang bekas atau limbah plastik menjadi suatu yang bernilai ekonomis dan estetika merupakan suatu hasil karya seni.

\section{5) Mathematics}

Matematika sebagai unsur utama dalam proses ini, tentu banyak aktivitas siswa terkait bidang matematika, khususnya materi Bangun Ruang Sisi Lengkung (BRSL). Tujuan pembelajaran pada materi BRSL ini adalah siswa dapat menyelesaikan masalah kontekstual yang berkaitan dengan luas permukaan dan volume BRSL.Untuk mencapai tujuan ini dilakukan melalui aktivitas siswa dalam membuat pot bunga dan rak.

Pot bunga dibuat dari bola plastik, botol plastik dan kaleng dengan berbagai ukuran. Pot bunga dari botol plastik dihias dengan melilitkan tali plastik berwarna pada bagian selimut botol (tabung). Ada juga kelompok yang menggunakan kaleng yang dililitkan dengan menggunakan kawat. Siswa diminta untuk memperhitungkan panjang tali plastik atau kawat yang digunakan untuk melilit botol dan kaleng. Siswa juga mengukur diameter dari botol dan kaleng. Pot dari bola plastik dibuat dengan membelah bola plastik menjadi dua bagian sehingga terbentuk setengah bola. Pot berbentuk setengah bola ini dilapis dengan menggunakan kertas karton berwarna. Siswa juga mengukur diameter dari bola dan menghitung luas karton minimal yang dibutuhkan untuk melapisi permukaaan setengah bola.

Pada laporan proyek, siswa diminta untuk menghitung luas permukaan botol plastik, kaleng dan setengah bola yang digunakan. Juga panjang lilitan tali plastik maupun kawat serta luas karton yang digunakan menghias pot. Ini terkait dengan indikator luas permukaan BRSL.

Pot diisi dengan tanah sebagai media tanam bunga. Siswa diminta untuk menghitung kebutuhan tanah yang digunakan untuk mengisi masing-masing pot yang berbentuk tabung dan setengah bola. Disamping itu, untuk pembuatan tiang-tiang rak digunakan potongan-potongan kayu berbentuk tabung. Siswa juga mengitung volume kayu tersebut dan ditulis dalam laporan proyek. Ini berkaitan dengan indikator menghitung volume BRSL. 
Berikut adalah gambaran suasana aktivitas siswa dalam pelaksanaan proyek.

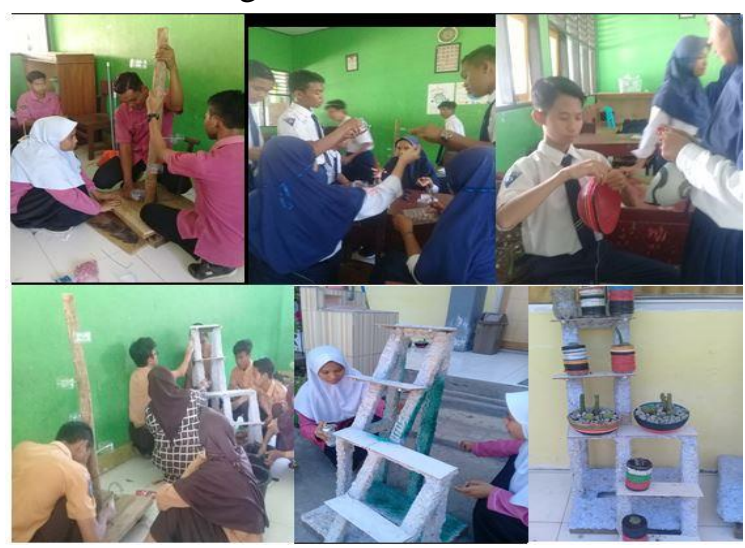

Gambar 1. Pelaksanaan proyek

Selama proses penyelesaian proyek, peneliti memonitoring aktivitas siswa dan melakukan penilaian terhadap kemampuan berpikir kreatif siswa dengan menggunakan lembar observasi.

Tabel 4. Hasil penilaian lembar observasi

\begin{tabular}{llccccc}
\hline \multirow{2}{*}{ No } & $\begin{array}{c}\text { Aspek berpikir } \\
\text { kreatif }\end{array}$ & \multicolumn{5}{c}{ Kelompok } \\
\cline { 3 - 7 } & & $\mathbf{1}$ & $\mathbf{2}$ & $\mathbf{3}$ & $\mathbf{4}$ & $\mathbf{5}$ \\
\hline 1 & Kelancaran & 3 & 3 & 3 & 3 & 3 \\
2 & Keluwesan & 2 & 3 & 2 & 3 & 2 \\
3 & Keaslian & 3 & 3 & 2 & 2 & 2 \\
4 & Keterperincian & 3 & 3 & 3 & 3 & 3 \\
Jumlah & 11 & 12 & 10 & 11 & 10 \\
\multicolumn{2}{l}{ Nilai } & $69 \%$ & $75 \%$ & $63 \%$ & $69 \%$ & $63 \%$ \\
\hline
\end{tabular}

Berdasarkan Tabel 4 terlihat bahwa rata-rata nilai adalah 68\% dengan kategori cukup baik. Dari empat aspek berpikir kreatif yang diobservasi masih dalam kategori baik dan cukup baik. Hal ini disebabkan oleh: (1) siswa masih belum banyak mengemukakan gagasan-gagasan baru terkait proyek yang dibuat, (2) pendapat/pandangan dalam menyelesaikan permasalahan kurang variatif, (3) siswa masih menunggu arahan dan bimbingan guru dalam melakukan prosedur kerja, (4) guru perlu memberikan pertanyaan-pertanyaan produktif untuk membantu siswa dalam mengatasi permasahan yang dihadapi. Kurang optimalnya kemampuan berpikir kreatif siswa ini karena pembelajaran yang dilakukan selama ini jarang melibatkan siswa secara aktif dalam mengemukakan gagasan atau pendapat sendiri. Hal ini sejalan dengan penelitian Putra \& Purwasih (2015) bahwa siswa yang secara aktif dalam pembelajaran memiliki hasil belajar yang lebih baik dibandingkan siswa yang hanya mencatat penjelasan guru.

Setelah menghasilkan produk dari hasil penyelesaian proyek, siswa diminta membuat laporan hasil proyek dan mempresentasikan hasil proyek berupa produk kepada guru dan siswa yang lain. Pada tahap ini guru menilai hasil laporan proyek dan produk yang dihasilkan tiap kelompok.

Produk yang dihasilkan siswa berupa rak bunga, meja, pot yang ditanami bunga dengan beraneka bentuk dari setiap kelompok. Bahan utama yang dipakai berasal dari plastik bekas, seperti bungkus/kantong plastik ataupun botol plastik. Hasil produk siswa ini dipakai untuk menghias teras dan pojok ruang kelas. Hasil penilaian produk kreatif siswa terlihat pada tabel berikut. 
Tabel 5. Hasil penilaian Produk kreatif

\begin{tabular}{|c|c|c|c|c|c|c|c|}
\hline \multirow{2}{*}{ No } & \multirow{2}{*}{$\begin{array}{c}\text { Komponen } \\
\text { Penilaian Produk }\end{array}$} & \multirow{2}{*}{$\begin{array}{c}\text { Aspek produk } \\
\text { kreatif / STEAM }\end{array}$} & \multicolumn{5}{|c|}{ Kelompok } \\
\hline & & & 1 & 2 & 3 & 4 & 5 \\
\hline 1 & Relevansi produk & Keterperincian & 4 & 4 & 4 & 4 & 4 \\
\hline 2 & Bentuk produk & Keaslian & 3 & 4 & 3 & 4 & 3 \\
\hline 3 & Fungsi produk & Pemecahan & 4 & 4 & 4 & 4 & 4 \\
\hline \multirow[t]{7}{*}{4} & \multirow{5}{*}{$\begin{array}{l}\text { Integrasi } \mathrm{S} \\
\text { dalam produk }\end{array}$} & Sains & 3 & 4 & 3 & 3 & 3 \\
\hline & & Teknologi & 4 & 4 & 4 & 4 & 4 \\
\hline & & Teknik & 3 & 3 & 3 & 3 & 3 \\
\hline & & Seni & 4 & 4 & 3 & 3 & 3 \\
\hline & & Matematika & 4 & 4 & 3 & 3 & 4 \\
\hline & \multicolumn{2}{|l|}{ Jumlah } & 29 & 31 & 27 & 28 & 28 \\
\hline & \multicolumn{2}{|l|}{ Nilai } & $91 \%$ & $97 \%$ & $84 \%$ & $88 \%$ & $88 \%$ \\
\hline
\end{tabular}

Berdasarkan Tabel 5 terlihat bahwa produk kreatif yang dihasilkan siswa sebagai hasil proyek memiliki nilai rata rata $90 \%$ dengan kategori sangat baik. Komponen penilaian produk berkategori sangat baik dan baik. Pada aspek keterperincian yang dikaitkan dengan komponen relevansi produk memperoleh nilai 100\% karena semua produk yang dibuat siswa relevan dengan materi BRSL. Pada komponen bentuk produk memperoleh nilai $85 \%$ karena produk merupakan hasil karya siswa sendiri dengan ide-ide yang berasal dari siswa. Fungsi produk (pemecahan) dengan nilai $100 \%$ memegang peranan penting dalam produk yang dihasilkan siswa karena merupakan solusi dari permasalahan yang ditimbulkan oleh banyaknya plastik bekas yang ada di sekolah setiap hari.

Produk yang dihasilkan juga telah memenuhi kriteria STEAM, dimana produk dibuat dengan menggunakan pengetahuan mereka tentang BRSL dan teknik yang sesuai, menggunakan teknologi dalam mendukung rancangan produk, perhitungan yang tepat, serta menambahkan unsur seni pada produknya.

Pada pelaksanaaan akhir proyek, siswa mempresentasikan produk hasil karya mereka dengan menjelaskan prosedur pelaksanaan proyek, mulai dari tahap perencangan sampai produk akhir. Selanjutnya guru meminta siswa untuk membuat laporan proyek. Untuk hasil penilaian laporan proyek terlihat pada Tabel 6 berikut.

Tabel 6 Hasil penilaian laporan proyek

\begin{tabular}{lll}
\hline No & Nama Kelompok & Nilai \\
\hline 1 & Kelompok 1 & $77 \%$ \\
2 & Kelompok 2 & $80 \%$ \\
3 & Kelompok 3 & $73 \%$ \\
4 & Kelompok 4 & $77 \%$ \\
5 & Kelompok 5 & $77 \%$ \\
\hline
\end{tabular}

Hasil laporan proyek siswa dalam kategori baik dengan nilai rata rata sebesar 77\%. Aspek berpikir kreatif memiliki nilai bervariasi dalam kategori baik dan cukup. Beberapa hal yang terlihat dari laporan proyek ini antara lain: (1) penyusunan konsep dasar teori dan judul relatif sama, siswa kurang mampu menuliskan dasar teori yang berbeda dengan yang lain (keaslian), (2) penyusunan tujuan yang menilai aspek kelancaran berkategori baik, siswa mampu merumuskan tujuan dengan lancar sesuai dengan materi yang ditugaskan, (3) siswa masih kurang mampu dalam merinci prosedur kerja, hasil dan pembahasan karya (keterperincian) karena siswa menuliskannya secara singkat dan kurang menuangkan gagasannya dalam memaparkan hasil dan pembahasan proyek, (4) siswa mampu 
membuat kesimpulan untuk menjawab tujuan dan menyertakan daftar pustaka yang sesuai dalam laporan (keluwesan).

Dari hasil analisis data dan aktivitas-aktivitas yang dilakukan siswa dalam pembelajaran PBPSTEAM tersebut menunjukkan bahwa pembelajaran ini dapat mengembangkan kreativitas siswa. Penerapan PBP-STEAM memberikan kesempatan kepada siswa untuk bebas berkreasi menghasilkan produk yang bagus dan menarik. Hal ini mendorong siswa untuk memiliki keterampilan kreativitas yang tinggi dengan cara mengimplementasikan ide-ide mereka, baik secara pribadi maupun kelompok

Hal ini sejalan dengan penelitian yang dilakukan oleh Hadinugrahaningsih, et al (2017) bahwa Pembelajaran Berbasis Proyek dengan pendekatan STEAM mendorong siswa memiliki keterampilan seperti keterampilan kreativitas yang dibutuhkan pada abad ke-21. Hal senada diungkapkan Wijaya (2015) bahwa STEAM dibutuhkan siswa-siswi Indonesia untuk melatih kemampuan menghadapi masalah abad 21.

Hasil lembar observasi sikap siswa dianalisis secara deskriptif. Pengamatan dilakukan baik pada saat pembelajaran maupun diluar jam pembelajaran yang dilakukan secara kontinu. Apabila seorang siswa pernah memiliki catatan sikap yang kurang baik, jika pada kesempatan lain peserta didik tersebut telah menunjukkan perkembangan sikap (menuju atau konsisten) baik pada aspek atau indikator sikap yang dimaksud, maka di dalam catatan ditulis bahwa sikap peserta didik tersebut telah (menuju atau konsisten) baik atau bahkan sangat baik. Dari hasil catatan perkembangan sikap, terlihat bahwa terjadi perubahan sikap siswa menuju ke arah sikap yang peduli terhadap lingkungan sekolah yang terlihat dari sebagian besar siswa memiliki predikat sangat baik.

Disamping itu, pemanfaatan plastik bekas yang ada di lingkungan bisa dimaksimalkan sehingga dapat menumbuhkan kepedulian siswa terhadap lingkungannya. Siswa bisa menyadari bahwa barang barang limbah seperti plastik dapat juga dimanfaatkan dan dibuat menjadi suatu karya seni. Jadi dalam membuat suatu karya/produk tidak selalu membutuhkan biaya yang mahal. Hal ini merupakan salah satu nilai karakter yang harus ditanamkan pada siswa, yaitu peduli lingkungan (Suyadi, 2013: 8).

\section{KESIMPULAN.}

Pembelajaran Berbasis Proyek dengan pendekatan STEAM yang dilakukan telah dapat mengembangkan kreativitas siswa, terutama kreativitas dalam produk kreatif yang mencapai kategori sangat baik dengan nilai 90\%. Sedangkan dalam kreativitas pada ranah berpikir kreatif masih perlu ditingkatkan dengan memberi kesempatan pada siswa secara aktif mengemukakan gagasan atau pendapatnya dalam kegiatan pembelajaran.

Produk yang dihasilkan siswa pada penugasan proyek dengan menggunakan bahan dari plastik bekas dapat menumbuhkan kepedulian siswa terhadap lingkungan, sebagai salah satu pendidikan karakter siswa.

\section{DAFTAR PUSTAKA}

Annisa, R., Effendi, M. H., \& Damris, D. 2018. Peningkatan Kemampuan Berpikir Kreatif Siswa dengan Menggunakan Model Project Based Learning Berbasis STEAM (Science, Technology, Engineering, Arts dan Mathematic) pada Materi Asam dan Basa di SMAN 11 Kota Jambi. Journal of The Indonesian Society of Integrated Chemistry, 10(2), 11-19.

Dirjen Dikdasmen. 2016. Panduan Pembelajaran Untuk Sekolah Menengah Pertama. Jakarta: Kementerian pendidikan dan kebudayaan

Ditjen GTK Kemendikbud. 2018. Buku Pegangan Pembelajaran Berorientasi pada Keterampilan Berpikir Tingkat Tinggi. Jakarta: Kementerian pendidikan dan kebudayaan

Hadinugrahaningsih, T., Rahmawati, Y., dan Ridwan, A. 2017. Developing 21 st century skilis in chemistry classrooms: opportunities and challenges of STEAM integration. In AIP Conference Proceedings, 1868(1), p.030008.

Henriksen, D. (2014) "Full STEAM Ahead: Creativity in Excellent STEM Teaching Practices" The STEAM Journal: 1(2), DOI: 10.5642 / steam. 20140102.15, diunduh 12 Desember 2018 pada https://scholarship.claremont.edu/steam/vol1/iss2/15.

Munandar, U. 2014. Pengembangan Kreativitas Anak Berbakat. Jakarta: Rineka Cipta. 
Putra, H. D., \& Purwasih, R. 2015. Meningkatkan Prestasi Belajar dan Keaktifan Mahasiswa Melalui Project Based Learning. Jurnal Ilmiah UPT P2M STKIP Siliwangi, 2(2), 128-136.

Suyadi. 2013. Strategi Pemebelajaran Pendidikan Karakter. Bandung: Remaja Rosdakarya.

Warsono dan Hariyanto. 2012. Pembelajaran Aktif Teori dan Asesmen. Surabaya: PT Remaja Rosdakarya.

Wijaya, A.D., Karmila, N. , Amalia, M.R. 2015. Implementasi Pembelajaran Berbasis STEAM (Science, Technology, Engineering, Art, Mathematics) Pada Kurikulum Indonesia. Proseding pada Seminar Nasional Fisika dan Aplikasinya. Universitas Padjadjaran Bandung.

Yakman, Georgette., Hyongyong, Lee. 2012. Exploring The Exemplary STEAM Education in the U.S. as a Practical Educational Framework for Korea. J Korea Assoc. Sci. Edu, 32(6), pp. 1072-1086. diunduh 15 Desember 2018 pada https://www.researchgate.net/publication/263634773_Exploring_the_Exemplary_STEAM_Education_i n_the_US_as_a_Practical_Educational_Framework_for_Korea. 